\title{
DAMPAK MEDIA SOSIAL INSTAGRAM BEM FISIP UNISKA TERHADAP SIKAP PERILAKU DAN PRESTASI AKADEMIK S1 FISIP UNIVERSITAS ISLAM KALIMANTAN MUHAMMAD ARSYAD AL-BANJARI BANJARMASIN \\ Ade Nur Atika Sari
}

Universitas Islam Kalimantan MAB Banjarmasin

Email : Adenuratikasari91@gmail.com

\begin{abstract}
ABSTRAK
Media sosial adalah salah satu alat komunikasi yang sering di gunakan masyarakat berkembangnya teknologi menjadi alasan terciptanya media sosial, jika dahulu media hanya berupa televisi, radio atau Koran maka lain halnya dalam media sosial di media sosial pengunanya dapat terhubung keseluruh dunia dan media sosial secara tidak sengaja menjadi kebutuhan penting seseorang dalam kehiduan sehari-hari dalam mencari informasi, promosi, berdagang dan lain-lain. Metode pendekatan dengan mengunakan tipe pada kuantitatif yang menghasilkan data deskriptif berupa pertanyaan-pertanyaan tertulis dari orang-orang pelaku yang dapat diamati, penelitian kuantitatif digunakan untuk meneliti hubungan di antara variable-variabel, dan hubungan variablevariabel. Dalam penelitian ini populasi adalah mahasiswa S1 Fisip Uniska, metode pengambilan data yang digunakan adalah metod survey ini melalui dating langsung kelapangan dengan di sertai menyebarkan angket kuensioner. Dari hasil penelitian ini dapat di simpulkan dampak media sosial terhadap sikap prilaku dan prestasi akademik mahasiswa tidak berpengaruh secara signifikan dapat diketahui dari Variable pengaruh media sosial instagram bem fisip uniska terhadap sikap dan prilaku remaja khususnya S1 Fisip Uniska dapat di lihat dari nilai koefiensi regresi $(\mathrm{R})=0,153$ bersifat positif, sedangkan nilai koefisien determinasi ( $\mathrm{R}$ Square) sebesar 0,023 ini dapat diartikan bahwa H0 diterima berarti tidak ada pengaruh secara signifikan dampak media sosial instagram bem fisip uniska terhadap sikap dan prilaku adalah 2,3\% dan sisanya 97,7\% dipengaruhi variable lain diluar dari penelitian.
\end{abstract}

Kata Kunci : Media sosial instagram, sikap dan prilaku, Prestasi akademik.

\section{PENDAHULUAN}

Globalisasi adalah proses integrasi internasional yang terjadi karena pertukaran pandangan dunia, produk, pemikiran dan aspekaspek kebudayaan. Globalisasi diartikan sebagai proses yang menghasilkan dunia tunggal dengan perkembangan bidang komunikasi dan traprortasi, dunia mengalami era globalisasi. Era dimana informasi seluruh dunia terbuka untuk semua orang prtlu diketahui dalam derasnya arusglobalisasi saat ini terdapat dampak positif dan negatifnya dengan kata lain globalisasi menimbulkan bahasa dan harapan.

Dampak globalisasi yang nampak adalah teknologi yang semakin canggih, segala sesuatu yang dibutuhkan dengan mudah didata, contoh saja handphone yang dengan mudahnya di dapat denga kualitas terjamin dan harga terjangkau, bahkan setiap hari selalu ada perubahan dan penambahan versi-versi terbaru. Teknologi dan Informasi di Indonesia semakin berkembang dan meningkat. Pertumbuhan tersebut di dukung oleh perkembangan pengguna perangkat mobile khususnya smartphone perkembangan teknologi tersebut tidak hanya berkembang di kota-kota besar saja namun juga sudah merambah ke kota kecil bahkan ke pedesaan, internet tidak hanya digunakan sebagai media berinteraksi dan komunikasi namun juga sebagai media promosi untuk menawarkan sebuah produk dan menampilkan tren masa kini yang sedang berkembang, salah satu bagian dari internet adalah media sosial.

Media sosial adalah sebuah media online dengan para pengunanya bisa dengna mudah berpartisipasi, berbagi dan menciptakan isi meliputi blog, jejaring sosial wiki, forum, dan dunia virtual, Blog jejaring sosial dan wiki merupakan bentuk media sosial yang paling umum diguankan oleh masyarakat diseuruh dunia media sosial merupakan sebuah situs diaman seseorang dapat membuat web pribadi dan terhubung dengan setiap orang yang bergabung dengan media sosial yang sama untuk berbagi informasi dan bekomunikasi, jika media tradisional mengunakan media cetak dan media broadcast dan media tradisional juga tidak mengunakan tekmologi seperti sekarang mereka lebih mengunakan seperti berita dikoran, televeisi atau radio tanpa mengunakan internet, media sosial mengajak siapa saja yang tertarik untuk berpartisipasi dengan feedback secara terbuka, memberi komentar, serta membagi informasi dalam waktu yang cepat dan tidak terbatas sangat mudah 
dan tidak membutuhkan waktu yang lama bagi seseorang dalam membuat akun dimedia sosial.

Pesatnya perkembangan media sosial juga dikarenakan semua orang seperti bisa memiliki media sendiri, jika untuk media tradisional seperti televise, radio atau koran dibutuhkan modal besar dan tenaga kerja yang banyak, maka lain halnya dengan media sosial para pengguna media sosial bisa mengakses jaringan internet tanpa biaya yang besar dan dapat dilakukan sendiri dengan mudah.

Media sosial memang menawarkan banyka kemudahan yang membuat para pengunanya betah berlama-lama berselancar di dunia maya, para penguna media sosial bebas berkomentar serta menyalurkan pendapat, tanpa rasa khawatir tidak ada batasan ruang dan waktu mereka dapat berkomunikasi kapanpun dan dimanapun mereka berada.

Pengguna media sosial yang paling dominan atau banyak adalah oleh kalangan remaja media sosial terbesar yang paling sering digunakan oleh kalangan remaja antara lain, Facebook, Twitter, Path, Youtube, Instagram, Kaskus, LINE, Whatsapp DLL masing-masing media sosial tersebut mempunyai keunggunlan khusus dalam menarik banyak pengguna media sosial yang mereka miliki.

Namun yang paling popular di masa skerang adalah media sosial instagram merupakan media sosial yang paling popular, popularitas instagram kian menjulang, seiring dengan meningkatnya jumlah penguna aplikasi tersebut, menurut CEO instagram Kevin Systrom jumlah pengguna aplikasi instagram tersebut memcapai 700 juta, dengan peningkatan 100 juta pengguna dalam waktu singkat. Media sosial pun dapat berdampak begativ atau positif terhadap penggunanya kalangan remaja yang mempunyai media sosial biasanya memposting terhadap kegiatan pribadinya, contohnya curhatannya serta foto-foto bersama dengan teman.

Dalam media sosial siapapun dapat dengan bebas berkomentar serta menyalurkan pendapatnya tanpa rasa khawatir. Hal ini dikarenakan dalam internet khususnya media sosial sangat mudah memalsukan jati diri atau melakukan kejahatan. Padahal dalam perkembangannya di sekolah, remaja berusaha mencari identitasnya dengan bergaul bersama teman sebayanya. Namun saat ini seringkali remaja beranggapan bahwa semakin aktif dirinya di media sosial maka mereka akan semakin dianggap keren dan gaul. Sedangkan remaja yang tidak mempunyai media sosial biasanya dianggap kuno atau ketinggalan jaman dan kurang bergaul.

Instagram banyak diguanakn masyarakat dibandingkan dengan facebook yang jutaan orang mengunakannya karna sekarang instagram yang sudah mulai berkembang denga cepat fitur-fitur yang diguanakan pun lebih banyak, remaja mendominasi berada di instagram karna mereka juga dapat melihat secara langsung kegiatan orang yang dimaksud rata-rata umur yang mengunakan media social instagaram itu sendiri dari anak 7 tahun sampai dengan ibu-ibu atau bapa-bapa yang sudah berumur pun bisa mengunakan instagram, sedangkan facebook sendiri banyak juga mengunakan naum lebih banyak ibu atau bapabapa yang mengunakannya karna fiturnya lebih gampang di banding instagram meskipun remaja ada media social facebook mereka mengunakannya hanya untuk pendaftaran game atau aplikasi yang didukung oleh facebook itu sendiri.

Dengan situs jejaring ini kita dapat memperluas pertemanan secara kekerabatan maupun dengan masyarakat luas, bukan hanya dalam ruang lingkup lingkungan tempat tinggal saja tetapi dari berbagai macam kalangan lingkungan maupun status sosial. Hal tersebut menjadi suatu kaharusan bagi remaja untuk memilikinya. Media sosial bagi para remaja merupakan hal yang penting tidak hanya sebagai tempat memperoleh informasi yang mernarik tetapi juga sudah menjadi lifestyle atau gaya hidup. Banyak pelajar yang tidak ingin dianggap jadul karena tidak memiliki akun media sosial. Media sosial bagi para remaja biasanya di gunakan untuk mengekspresikan diri, berbagai segala tentang dirinya kepada banyak orang terutama temanteman dan media sosial juga bisa dijadikan sebagai tempat untuk menghasilkan uang.

\section{RUMUSAN MASALAH}

1. Bagaimana pengaruh instagram di jaman moderin ini terhadap sikap dan perilaku remaja khusunya mahasiswa S1 Fisip UNISKA ?

2. Bagaimana pengaruh media sosial instagram terhadap prestasi akademik mahasiswa?

3. Apakah ada pengaruh instagram bem fisip uniska terhadap tingkat kerajinan mahasiswa?

\section{TINJAUAN PUSTAKA}

\section{Komunikasi Massa}

Saat ini kita bicara tentang komunikasi massa komunikasi massa (mass communication) merupakan proses menciptakan kesamaan arti antara media massa dengan khalayak mereka. Schramm menampilkan ulang model yang ia buat sebelumnya dengan mengabungkan dari model Osgood yang membantu kita memberi gambaran aspek particular tentang proses komunikasi massa. Contohnya jika pada model awal "pesan" hanya satu model komunikasi massa memperlihtakan “ berbagai pesan identik " dalam penjelasannya model komunikasi massa lebih menyorot secara spesifik " timbal balik “ sedangkan model komunikasi interpersonal tidak. Ketika dua orang 
atau beberapa orang berkomunikasi secara tatap muka, partisipasi dapat secara cepat dan jelas mengenali adanya timbal balik dalam timbal balik pesan ( professor kita yang membosankan dapat melihat dan mendengarkan ketidaksenangan mahasiswa saat mendengar penjelasan pelajaran ), sementara pada komunikasi massa tidak semudah itu.

Dalam model komunikasi massa milik Schramm timbal balik merupakan perwakilan dari garis titik-titik yang dinamakan TIMBAL BALIK INFERENSIAL ( inferential feedback ) timbal balik ini bersifat tidak langsng contohnya para eksekutif televise harus menunggu minimal satu hari atau terkadang satu bulan untuk mengetahui rating dari sebuah. Program acara bahkan rating yang hanya melihat orang yang melihat acara tersebut dan bukannya mengetahui kesukaan atau ketidaksukaan orang terhadap program hasilnya para eksekutif ini hanya dapat menerka apa yang mereka harus perbaiki dari program tersebut.

Oleh karena itu timbal balik tersebut dinamakan timbal balik inferensial, komunikasi mssa dan juga subjek dari penambhan timbal balik biasanya dalam bentuk kritik di media lain seperti televise mengkritik tulisan sebuah kolom di surat kabar. (buku pengantar komunikasi massan, literasi media dan budaya "Stanley J. Baran "Tahun 2011).

\section{Media Sosial}

Media social adalah sebuah media daring, dengan para pengunanya bias dengan mudah berpartisipasi bebagi dan menciptakan isi blok, jejaring social, wiki, forum dan dunia virtual. Blok, jejaring social dan wiki meruapakan bentuk media social yang paling umum diguanakan oleh masyarakat di seluruh dunia.

Andreas Kaplan dan Michael Haenlein mendefinisikan media social berbagai " sebuah kelompok aplikasi berbasis internet yang membangun di atas dasar ideologi dan teknologi. Media social berciri-ciri sebagai berikut pesan yang disampaikan tidak hanya satu orang saja namun bias keberbagai banyak orang contonya pesan melalui sms ataupun internet, pesan yang disampaikan bebas tanpa harus melalui suatu Gatekeeper, pesan yang disampaikan cenderung lebih cepat di bandingkan media lainnya, penerima pesan yang menetukan waktu interaksi.

Pada tahun 2010 lahirnya instgaram situs jejaring social yang memungkinkan penggunanya untuk membagikan foto-fotonya dengan mudah, awalnya hanya untuk penguna IOS, tetapi sejak tahun 2012 juga hadir untuk pengguna android.

Pesatnya perkembangan media social masa kini dikarenakan semua orang seperti biasa memiliki media sendiri jika memiliki media tradisional seperti televise, radio atau Koran di butuhkan modal yang besar dan tenaga kerja yang banyak maka lain halnya dengan media social digital, seseorang penguna bias mengakses media social dengan akses jaringan internet yang lambat sekalipun tanpa biaya besar tanpa alat mahal dan dilakukan sendiri tanpa memerlukan karyawan, penguna media social dengan bebas bias mengedit, menambahkan, memodifikasi baik tulisan, gambar, video, grafis dan berbagai model content lainnya.

Media social adalah mengenai menjadi manusia biasa yang saling membagi ide, bekerjasama dan bekolaborasi untuk menciptkan kreasi, befikir, berdebat, menemukan pasangan, membangun sebuah komunitas, intinya mengunakan media social menjadikan kita sebagai diri sendiri selain kecepatan informasi yang bias diakses dalam hitungan detik, menjadi diri sendiri dalam media social adalah alas an mengapa media social berkembang pesat rak terkecuali, keinginan untuk aktuaslisasi diri dan kebutuhan menciptakan personal branding.

Kerangka sarang lebah mendifisinikan bagaiaman media social layananan focus pada beberapa atau tujuh blok bangunan blok tersebut membantu memahami kebutuhan pertunangan dari audiens media social sebagai contoh, pengguna linkedln peduli kebanyakn tentang identitas, reputasi dan hubungan, sedangkan bebagai, percakapan, kelompok dan reputasi.

Sementara jejaring social merupakan situs dimana setiap orang bisa membuat web page pribadi, kemudian terhubung dengan teman-teman untuk berbagi informasi dan berkomunikasi jejaring social terbesar antara lain facebook, Myspace, Plurk dan Twitter, jika media trasidional mengunakan media cetak dan media broadcast maka medis social mengunakan internet, media social mengajak siapa saja yang tertarik untuk berpartisipasi denagn memberikan kontribusi dan feedback secara terbuka memberikan komentar serta membagi informasi dalam waktu yang cepat dan tak terbatas.

Saat teknologi internet dan mobile phone makin maju maka media social pun ikut tumbuh pesat kini untuk mengakses facebook atau twitter misalnya bias dilakukan dimana saja dan kapan saja hanya mengunakan sebuah mobile phone demikian cepatnya orang bias mengakses media social mengakibatkan terjadinya fenomena besar terhadap arus informasi tidak hanya dinegaranegara maju tetapi juga di Indonesia karena kecepatannya media social juga mulai tampak mengantikan perannan media massa konvensiona dalam menyebarkan berita-berita.

Collaborative projects memungkinkan adanya kerjasama dalam kreasi konten yang dilakukan oleh beberapa pengguna secara simultan, misalnya adalah Wikipedia. Beberapa situs jenis ini mengizinkan penggunanya untuk melakukan penambahan, menghilangkan, atau mengubah konten. Bentuk lain dari collaborative projects 
adalah social bookmarking yang mengizinkan koleksi berbasis kelompok dan peringkat kaitan internet atau konten media.

\section{Perilaku}

Perilaku adalah suatu kegiatan atau aktifitas organisme (makhluk hidup) yang bersangkutan, oleh sebab itu sudur pandang bilogis semua makhluk hidup mulai tumbuh-tumbuh, binatang sampai manusia itu berperilaku karena mereka mempunyai aktifitas masing-masing.

Menurut skinner (1938) seorang ahli psikologis, merumuskan respon atau reaksi seseorang terhadap stimulus (rangsangan dari luar), oleh karena itu perilaku ini menjadi terjadi melalui proses adanya stimulus terhadap, organisme, dan kemudian organisme tersebut merepons, maka teori Skinner ini disebut teori "S-O-R" atau stimulus organisme respons.Skinner di bedakan adanya dua respon.

1. Respondent respons atau flexi, yakni respon yang ditimbulkan oleh rangsanganrangsangan (stimulus) tertentu. Stimus semacam ini disebut electiving stimulalation karena menimbulkan respon-respon yang relatif tetap.

2. Operant respons atau instrumental respons, yakni respon yang timbul dan berkembang diikuti oleh stimus atau perangsang ini disebut reinforcing atau reinforcer karena mencakup respon.

3. Perilaku terbuka (overt Behavior) respon terhadap stimulus tersebut sudah jelas dalam atau praktik (practice) yang dengan mudah diamati atau dilihat orang lain.

Domain perilaku adalah bentuk respon atau reaksi terhadap stimulus atau rangsangan dari luar organisme (orang), namun dalam memberikan respon sangat tergntung pada karakteristik atau faktor-faktor lain dari orang yang bersangkutan, faktor-faktor yang membedakan respon terhadap stimulus yang berbeda yang disebut deteminan perilaku. Deteminan perilaku ini dapat dibedakan menjadi dua yakni :

1. Determinan atau faktor internal, yakni karakteristik orang yang bersangkutan, yang bersifat given atau bawaan, misalnya tingkat kecerdasan, tingkat emosional, jenis kelamin dan sebagainya.

2. Determinan atau faktor eksternal, yakni lingkungan, baik lingkungan fisik, sosial, budaya, ekonomi, politik, dan sebagainya.Faktor lingkungan ini sering merupakan faktor yang dominan yang mewarnai perilaku seseorang.

Benyamin (1908) yang dikutip Notoatmodjo 2007, membagi perilaku manusia kedalam 3 domain ramah atau kawasan yakni : kognitif (cognitive), afektif (affective), dan psikomotor (psychomor) dalam perkembangan, teori ini dimodifikasi untuk pengukuran hasil pendidikan kesehatan yakni : pengetahuan, sikap dan praktik atau tindakan (Notoatmodjo 2007).

\section{Sikap}

Ada banyak penjelasan mengenai sikap dalam ilmu psikologi. Sikap memiliki banyak sekali pengertian karena banyaknya pendapat-pendapat yang berbeda menurut para ahli. Sikap biasanya selalu terarahkan pada suatu hal ataupun suatu objek. Sikap mungkin saja terarahkan pada sebuah benda ataupun orang, namun juga pada peristiwa, lembaga, normal, nilai, lembaga, serta lain sebagainya. Ada beberapa pengertian sikap menurut para ahli, antara lain adalah:

Menurut Sarnoff, Sikap menjadi sebuah kesediaan yang diperuntukkan bereaksi , entah itu secara positif maupun negatif pada objek-objek tertentu.

Menurut D.Krech \& R.S Crutchfield, sikap sebagai sebuah organisasi yang memiliki sifat menetap dari sebuah proses emosional, motivasional, perseptual, serta kognitif yang berkaitan dengan aspek dunia individu.

Menurut La Peirre, sikap sebagai sebuah pola perilaku, kesiapan antisipatif, dan predisposisi yang mana digunakan untuk dapat menyesuaikan diri di dalam situasi sosial. Sederhanya, sikap merupakan respon pada stimuli sosial yang sudah terkondisikan.

Menurut Soetarno, sikap merupakan pandangan maupun perassaan yang mana disertai dengan kecenderungan untuk bisa bertindak pada objek tertentu. Sikap senantiasi diarahkan pada benda, orang, pandangan, peristiwa, norma, lembaga, dan lainnya.

Teori Insentif

Teori Insetif memiliki pandangan dalam pembentukan sikap sebagai sebuah proses dalam menimbang baik serta buruknya dengan berbagai kemungkinan posisi dan setelah itu mengambil solusi alternatif. Salah satu pendekatan insentif yang cukup populer adalah teori respons kognitif.

Kemudian, di dalam teori tersebut mengasumsikan jika seseorang akan memberikan responspada suatu komunikasi dengan menggunakan beberapa pikiran baik itu positif maupun negatif. Serta di dalamnya juga menjelaskan jika pikiran ini nantinya akan menentukan apakah seseorang berkeinginan untuk mengubah sikapnya atau tidak sebagai bentuk akibat dari komunikasi.

Melalui pendekatan ini terdapat asumsi jika dalam pengambilan sikap, maka seseorang tersebut akan berusaha untuk bisa memaksimalkan nilai dari berbagai hasil maupun akibat yang diinginkan. Dalam teori intensif, lebih menekankan pada keuntungan maupun kerugian yang bisa didapatkan seseorang saat mengambil posisi tertentu. Selain itu teori intensif juga lebih mengabaikan pada asal usul 
dari sebuah sikap serta hanya mempertimbangkan pada kesimbangan insentif yang sudah terjadi.

\section{Instagram}

Instagram adalah sebuah aplikasi berbagi foto dan viseo yang memugkinkan penguna mengambil foto,mengambil video, menerapkan filter digital dan membagikan ke berbagai layanan jejaring sosial termasuk instagram sendiri, satu fitur yang unik di instagram adalah memotong foto menjadi bentuk persegi, sehingga terlihat seperti hasil kamera kodak instamtic dan polaroid.

Perusahaan Burn, Ibc Berdiri pada tahun 2010 perusahaan teknologi startup yang hanya berfokus kepada pengembangan aplikasi untuk telpon genggam pada awal Burbn, Inc sendiri memiliki fokus yang terlalu banyak didalam HTML5 peranti bergerak namun Ceo Kevin Systrom dan Mike Krieger memutuskan untuk lebih fokus pada satu hal saja setelah satu minggu mereka mencoba untuk membuat sebuah ide yang bagus pada akhirnya mereka membuat sebuah versi pertama dari Burn namun didalamnya masih ada beberapa yang belum sempurna bersi Burn yang sudah final aplikasi yang sudah dapat diguanakn iPhone yang isinya terlalu banyak fitur-fitur sulit bagi kevin Systrom dam Mike Krieger untuk mengurangi fitur-fitur yang ada dan memulai lagi dari awal, namun akhirnya mereka hanya memfokuskan pada bagian foto, komentar dan juga kemampuan untuk menyukai sebuah foto itulah yang akhirnya menjadi instagram.

Nama instagram berasal dari pengertian dari keseluruhan fungsi aplikasi ini "insta" instagram yang dapat menampilkan foto-foto secara instan, seperti polaroid di dalam tampilannya, sedangkan untuk kata "gram" berasal dari kata "telegram" yang cara kerjanya untuk mengoromkan informasi kepada orang lain dengan cepat oleh karena itu instagram merupakan gabungan dari kata insta dan telegram.

Pada tanggal 9 april 2012 diumumkan bahwa instagram akan mengambil alih facebook senilai hampir \$1 miliar dalam bentuk tunai dan saham, pada tanggal 11 mei 2016 instagram memperkenalkan tampilan baru sekaligus ikon baru dan desain aplikasi baru terinpirasi oleh ikom aplikasi sebelumnya, ikon baru merupakan kamera sederhana dan pelangi hidup dalam bentuk gradien.

Pengikut, sistem sosial didalam instagram adalah dengan mnjadi mengikuti akun penguna lainnya atau memiliki pengikut instagram dengan demikian komunikasi antar sesama penguna instagram sendiri dapat terjalin dengan memberikan tanda suka dan juga mengomentari foto-foto yang telah diunggah oleh penguna lainnya dan jumlah tanda suka dari pengikut sangat memperngaruhi apakah foto tersebut dapat menjadi sebuah foto yang populer atau tidak, untuk menemukan teman-teman yang ada di dalam instgram dapat mengunakan teman-teman mereka yang juga mengunakan instagram melalui jejaring sosial seperti Twitter dan juga facebook.

Menggugah foto kegunaan dari instgram adalah sebagai tempat untuk menggugah dan berbagi foto-foto kepada penguna lainnya, foto yang ingin diunggah dapat diperoleh melalui kamera iDevice ataupun foto-foto yang ada di dalam album foto di iDevice tersebut, kamera foto yang telah di ambil melalui aplikasi instagram dapat disimpan di dalam iDevice tersebut penguna kamera melalui instgarm juga berlangsung mengunakan efek-efek yang ada, untuk mengatur pewarnaan dari foto yang dikehendaki oleh sang penguna, ada juga efek kamera tilt-shift yang fungsinya adalah untuk memfokuskan sebuah foto pada satu titik tertentu setelah foto diambil melalui kamera di dalam instgram foto tersebut juga dapat diputar arahnya sesuai dengan keinginan para penguna, maka pengguna akan dibawa ke halaman selanjutnya untuk menyunting foto tersebut.

\section{Komunikasi}

Komunikasi atau communication berasal dari bahasa latin communis yang berarti "sama" secara sederhana komunikasi dapat terjadi apabila ada kesamaan antara penyampaian pesan dan orang yang menerima pesan oleh sebab itu komunikasi bergantung pada kemampuan kita untuk dapat memahami satu sama dengan lainnya.

Menurut CARL I HOVLAN ilmu komunikasi adalah upaya yang sistematis untuk merumuskan secara tugas asa-asa penyammpaikan serta pembentukan pendapat dan sikap objek study ilmu komunikasi bukan saja penyampain informasi melainkan juga pembentukan pendapat umum dan sikap politik (publik attitude).

Teori use and gratification adalah sekelompok orang atau orang itu sendiri diangap aktiv dan selektiv mengunakan media sebagai cara untuk memenuhi kebutuhannya, studi pada bidang ini memusatkan perhatian pada penggungunaan (uses) media untuk mendapatkan kepuasaan (Gratifications) atas kebutuhan seseorang oleh karena itu sebagai perilaku orang tersebut akan dijelaskan melalui kebutuhan individu.

Pendapat lain mengenai definisi use and gratifications adalah teori pengunaan dan pemenuhan kebutuhan yang dalam bahasa inggris Uses and Gratification theory adalah salah satu teori komunikasi (massa) dimana titik berat penelitian ini dilakukan dilakukan pada pemirsa atau khalayak sebagai penentuan pemilihan pesan dan media.

Uses Gratifications Theory yang merupakan salah satu dari teori komunikasi massa melihat audiesn dari proses komunikasi massa sebagai individu yang aktif, selektif dan memiliki tujuan tertentu terkait dengan terpaan media kepadanya, artinya individu atau audiens (khalayak) sebgai 
makhluk sosial mempunyai sifat dalam menerima pesan yang ada dalam media massa.

Seperti ilmu-ilmu lainnya, ilmu komunikasi pun memiliki gejala komunikasi. Tidak hanya dengan pendekatan secara ontologis (apa itu komunikasi) tetapi juga secara aksiologis (bagaimana berlangsungnya komunikasi yang efektif) dan secara empistemologis (untuk apa komunikasi itu dilakukan) proses komunikasi pada hakikatnya adalah proses penyampaian pikiran atau perasaan oleh seseorang (komunikator) kepada orang lain (komunikan) pikiran bisa merupakan gagasan, informasi, opini dan lain-lain yang muncul dari benaknya perasaan bis berupa keyakinan, kepastian, keragu-raguan, kekhawatiran, kemarahan, keberanian, kegairahan, dan sebagainya yang timbul dalam lubuk hati.

Adakalanya seseorang menyampaikan sebuah pikirannya kepada orang lain tanpa menampakan perasaan tertentu. Pada saat orang lain menyampaikan perasaanya kepada orang lain tanpa pemikiran, tdak jarang pula seseorang menyampaikan pikiran disertai perasaan tertentu disadari atau tidak di sadari.

Komunikasi secara primer adalah proses penyampaian pikiran dan atau perasaan seseorang kepada orang lain dengan mengunakan lambang(symbol) sebagai media, lambang sebagai media primer dalam proses komunikasi adalah bahasa kial, isyarat, gambar, warna dan lain sebagainya yang secara langsung mampu menerjemahkan pikiran atau perasaan komunikator kepada komunikan.

\section{Prestasi Akademik}

Prestasi akademik merupakan perubahan dalam hal kecakapan tingkah laku, ataupun kemampuan yang dapat bertambah selama beberapa waktu dan tidak disebabkan proses pertumbuhan. Tetapi adanya situasi belajar, perwujudan bentuk hasil proses belajar tersebut dapat berupa pemecahan lisan maupun tulisan, dan keterampilan memcahkan masalah langsng dapat dikur atau dinilai dengan mengunakan tes yang berstandar.

Prestasi akademik adalah istilah untuk mewujudkan suatu pencapaian tingkat keberhasilan tentang suatu tujuan keran usaha belajar telah dilakukan oleh seseorang secara optimal. Contoh prestasi akademik seperti juara olimpiade sains, nilai Ipk lulus dengan cumlaude,dan rangking 1 dikelas. Pendek kata akademik berkaitan dengan kegiatan formal yang dilakukan sebuah instuti atau lembaga ternetu dengan syarat tertentu pula contoh sekolah dan universitas, sedangkan non akademik adalah kegiatan non formal dimana kita bisa mendapatkan kemampuan-kemampuan diaman saja dan tidak harus dari lembaga instuti tertentu contoh adalah kemapuan berkomunikasi dengan baik.

\section{Hipotesis}

Hipotesis penelitian ini adalah :

Ingin mengetahui apakah media sosial instagram bem fisip uniska berdampak pada prestasi akademik Mahasiswa S1 Fisip UNISKA Banjarmasin. Yang mana media sosial adalah suatu kebutuhan yang semua orang punya mau itu anakanak, remaja dan orang tua sekalipun dan media juga bisa bersifat positif atau negatif bagi para pengunanya.

$\mathrm{H}_{0}$ : Tidak ada pengaruh secara signifikan antara media sosial instagram bem fisip uniska terhadap sikap dan perilaku prestasi akademik mahasiswa.

$\mathrm{H}_{1}$ : ada pengaruh secara signifikan antara media sosial instagram bem fisip uniska terhadap sikap, perilaku dan pretasi akademik mahasiswa.

\section{METODE PENLITIAN}

Tipe penelitian ini adalah penelitian korelasional pendekatan kuantitatif deskripsi penelitian korelasional digunakan untuk meneliti hubungan antara variable-variabel dan hubungan dari variable-variabel itu disebut sebagai korelasi. Husein umar dalam bukunya metode penelitian organisasi menyebutkan bahwa penelitan korelasi adalah dirancang untuk menentukan tingkat hubungan variable-variabel yang berbeda dalam satu populasi perbedaan utama dengan metode ini adalah adanya usaha untuk menaksi hubungan dan bukan sekedar deskripsi sedangkan Jalaludin Rakhmat dalam bukunya metode penelitian komunikasi mengatakan bahwa metode korelasi bertujuan untuk meneliti sejauh mana variasi pada satu faktor yang berkaitan dengan variasi pada faktor lain. Bila hanya dua variable yang dihubungkan korelasinya disebut korelasi sederhana ( simple Correlation ).

Penelitian ini merupakan korelasi sederhana karena hanya menghubungkan dua variable yaitu sikap perilaku dan variable prestasi akademik mahasiswa.

\section{Skala Likert}

Skala Likert digunakan untuk mengukur sikap, pendapat, dan persepsi seseorang atau sekelompok orang tentang fenomena sosial. Dengan Skala Likert, variabel yang akan diukur dijabarkan menjadi indikator variabel. Kemudian indikator tersebut dijadikan sebagai titik tolak untuk menyusun item-item instrumen yang dapat berupa pertanyaan atau pernyataan. Jawaban setiap item instrumen yang menggunakan Skala Likert mempunyai gradasi dari sangat positif sampai sangat negatif, yang dapat berupa kata-kata antara lain: Sangat Penting (SP), Penting (P), Ragu-ragu (R), Tidak Penting (TP), Sangat Tidak Penting (STP).

Prosedur dalam membuat skala Likert adalah sebagai berikut: 
1. Peneliti mengumpulkan item-item yang cukup banyak, relevant dengan masalah yang sedang diteliti, dan terdiri dari item yang cukup jelas disukai dan tidak disukai.

2. Kemudian item-item itu dicoba kepada sekelompok responden yang cukup representatif dari populasi yang ingin diteliti.

3. Responden di atas diminta untuk mengecek tiap item, apakah ia menyenangi $(+)$ atau tidak menyukainya (-). Respons tersebut dikumpulkan dan jawaban yang memberikan indikasi menyenangi diberi skor tertinggi. Tidak ada masalah untuk memberikan angka 5 untuk yang tertinggi dan skor 1 untuk yang terendah atau sebaliknya. Yang penting adalah konsistensi dari arah sikap yang diperlihatkan. Demikian juga apakah jawaban "setuju" atau "tidak setuju" disebut yang disenangi, tergantung dari isi pertanyaan dan isi dari item-item yang disusun.

4. Total skor dari masing-masing individu adalah penjumlahan dari skor masingmasing item dari individu tersebut.

5. Respon dianalisis untuk mengetahui itemitem mana yang sangat nyata batasan antara skor tinggi dan skor rendah dalam skala total. Misalnya, responden pada upper $25 \%$ dan lower $25 \%$ dianalisis untuk melihat sampai berapa jauh tiap item dalam kelompok ini berbeda. Item-item yang tidak menunjukkan beda yang nyata, apakah masuk dalam skortinggi atau rendah juga dibuang untuk mempertahankan konsistensi internal dari pertanyaan.

Skala Likert dianggap lebih baik dari skala Thurstone, karena:

1. Dalam menyusun skala, item-item yang tidak jelas menunjukkan hubungan dengan sikap yang sedang diteliti masih dapat dimasukkan ke dalam skala. Dalam menyusun skala Thurstone, yang dimasukkan hanya item-item yang telah disetujui bersama dan jelas berhubungan dengan sikap yang ingin diteliti saja yang dapat dimasukkan.

2. Skala Likert lebih mudah membuatnya dibanding skala Thurstone.

3. Skala Likert mempunyai reliabilitas yang relatif tinggi dibandingkan dengan skala Thurstone untuk jumlah item yang sama. Makin banyak jumlah item, maka makin kurang reliabilitasnya. Skala Likert dapat memperlihatkan item yang dinyatakan dalam beberapa respons alternatif ( $\mathrm{SS}=$ sangat setuju, $\mathrm{S}=$ setuju, $\mathrm{R}=$ ragu-ragu, TS=tidak setuju, STS=sangat tidak setuju).
Sedangkan skala Thurstone hanya membuka dua alternatif saja.

4. Karena jangka responsi yang lebih besar membuat skala Likert dapat memberikan keterangan yang lebih jelas dan nyata tentang pendapatan atau sikap responden tentang isu yang dipertanyakan.

\section{Metode Analisi Kuantitatif}

Dalam penelitian ini model dan teknik analisis data mengunakan pendekatan Analisis Regresi Ganda. Sebelum dilakukan analisis regresi terlebih dahulu dilakukan uji kualitas intrumen penelitian yang diolah menggunakan IBM SPSS ( Statistic Product and service solution ) Versi 20 for windows.

\section{HASIL DAN PEMBAHASAN}

Instagram Mampu Mengasah Kemampuan Seseorang Dalam Bidang Tertentu.

Menunujukan bahwa instagram mampu mengasah kemampuan seseorang dalam bidang tertentu, hal ini dapat terlihat dari tanggapan positif $100 \%$ dengan rincian sangat setuju sebesar 13,3\% dan setuju sebesar 86,7\%, sedangkan untuk jawaban cukup setuju, dan untuk yang memilih tidak setuju dan hasil dari sangat tidak setuju tidak ada yang memilih. Dengan demikian dapat diketahui bahwa instagram mampu mengasah kemampuan seseorang dalam bidang tertentu.

\section{Bem Fisip Uniska Mengunakan Instagram Untuk Memberikan Informasi Kepada} Mahasiswanya Apakah Itu Berpengaruh Baik.

Meunujukan bahwa sebesar $16,7 \%$ responden memilih jawaban sangat setuju, dan sebesar $63,3 \%$ responden memilih jawaban setuju, 20\% responden yang memilih jawaban cukup setuju dan jawaban tidak setuju dan sangat tidak setuju tidak ada yang memilih. Dapat disimpulkan bahwa instagram bem fisip uniska di tanngapi baik oleh mahasiswa sebagai sumber informasi mereka tentang kampus dan fakultas.

\section{Instagram Berdampak Positif Terhadap Sikap Seseorang.}

Menunjukan jawaban responden 3,3\% sangat setuju, dan $80 \%$ responden menjawab setuju bahwa instagram berdampak positif terhadap sikap seseorang, dan $16,7 \%$ responden menjawab cukup setuju, dan responden yang menjawab tidak setuju dan jawaban sangat tidak setuju tidak ada yang memilih. Dapat di simpulkan bahwa instagram bisa berdampak positif bagi pengunanya jika digunakan dengan baik.

\section{Instagram Berdampak Negatif Terhadap Perilaku Seseorang. \\ Tabel 10 menunjukan $6,7 \%$ responden menjawab sangat setuju, dan $86,7 \%$ responden}


menjawab setuju bahwa instagram bisa berdampak negatif terhadap perilaku seseorang, dan responden yang menjawab cukup setuju sebesar $6,7 \%$ dan untuk jawaban tidak setuju dan sangat tidak setuju tidak ada yang memilih. Dapat di simpulkan bahwa instagram bisa berdampak negatif bagi perilaku seseorang jika sering mengunakannya.

Instagram Sering Mengubah Perilaku Mereka Secara Tidak Langsung Karna Apa Yang Mereka Lihat Membawa Dampak Begitu Juga Dengan Melihat Kegiatan Bem Fisip Uniska Membuat Mereka Lebih Mengenal Kampus.

Menunjukan jawaban responden yang menjawab sangat setuju sebesar $6,7 \%$ dan jawaban setuju sebesar $83,3 \%$ bahwa instagram sering mengubah perilaku mereka secara tidak langsung karna apa yang mereka lihat membawa dampak, dan sebesar $10 \%$ responden menjawab cukup setuju dan di jawaban tidak setuju dan sangat tidak setuju tidak ada yang memilih. Kesimpulan dari jawaban responden adalah bahwa instagram secara tidak langsng dapat berdampak megubah perilaku mahasiwa secara tidak langsung begitu juga dengan melihat kegiatan bem fisip uniska membuat mereka lebih mengenal kampus.

\section{Hasil Pengujian Normalitas Kolmogorov-} Smirnov

$\mathrm{H}_{0}$ : Populasi data/nilai Variabel $\mathrm{X}$ berdistribusi normal, $\mathrm{H}_{1}$ : Populasi data/nilai Variabel X tidak Berdistribusi normal, Ketentuan penerima/penolakan $\mathrm{H} 0$ sbb, jika sig <ó $(0,05)$ maka $\mathrm{H}_{0}$ di tolak, $\mathrm{H}_{1}$ diterima, jika sig $>\alpha \dot{\alpha}(0,05)$ maka $\mathrm{H}_{0}$ diteima, $\mathrm{H}_{1}$ di tolak.

Kesimpulan : nilai Kolmogrov-Smirnov $\mathrm{Z}$ =1.236, Most Extrem Differences Positif = 0,226, Dan nilai Asymp Sig = 0,094 >á (0,05). Maka, $\mathrm{H}_{0}$ di terima, $\mathrm{H}_{1}$ ditolak.

\section{Uji Asumsi Homogenitas Bartlett}

$\mathrm{H}_{0}$ : populasi data/nilai variable $\mathrm{X}$ berasal dari populasi homogen.

$\mathrm{H}_{1}$ : populasi data/nilai variable $\mathrm{X}$ bukan berasal dari populasi homogen.

Ketentuan penerima/penolakan $\mathrm{H} 0 \mathrm{sbb}$, Jika sig $<\alpha(0,05)$ maka $\mathrm{H}_{0}$ di tolak, $\mathrm{H}_{1}$ diterima, Jika sig $>\alpha(0,05)$ maka $\mathrm{H}_{0}$ diterima, $\mathrm{H}_{1}$ di tolak.

Pada Output Test Results menjelaskan bahwa Nilai Box's M diperoleh 704 dengan nilai Sig 0,715 .

Kesimpulan : karena nilai Sig Box'M sebesar $0,715>\alpha(0,05)$ maka $\mathrm{H}_{0}$ diterima $\mathrm{H}_{1}$ ditolak ( nilai variable $\mathrm{X}$ berasal dari populasi homogen).

\section{Heteroskedastisat.}

Nilai sig Y1 dan Y2 semuanya lebih besar dari 0,05, maka dapat disimpulkan bahwa baik Y1 dan Y2 telah terjadi gejala Heroskedastisitas.

Model Summary Uji Autokorelasi. Perhatikan output Coefficients berdasarkan output di atas, nilai Durbin-Watson (DW) di peroleh sebesar 1.419.

Kesimpulan : karena nilai DW $=1.419$ berada di bawah $\mathrm{dL} \leq \mathrm{d} \leq \mathrm{d}$ atau diantara batas bawahlower bound $(\mathrm{dl}=1.3384$ dan batas upper bound $(\mathrm{du}=$ 1,6589 berari berada diluar daerah autokorelasi.

\section{KESIMPULAN}

Berdasarkan hasil penelitian dan pembahasan pada bab-bab sebelumnya maka dapat diambil suatu kesimpulan sebagai berikut:

1. Variable pengaruh media sosial instagram bem fisip uniska terhadap sikap dan perilaku remaja khususnya S1 Fisip Uniska dapat di lihat dari nilai koefiensi regresi $(\mathrm{R})=0,153$ bersifat positif, sedangkan nilai koefisien determinasi ( $\mathrm{R}$ Square) sebesar 0,023 ini dapat diartikan bahwa H0 diterima berarti tidak ada pengaruh secara signifikan dampak media sosial instagram bem fisip uniska terhadap sikap dan perilaku adalah $2,3 \%$ dan sisanya $97,7 \%$ dipengaruhi variable lain diluar dari penelitian.

2. Variable dampak media sosial instagram terhadap prestasi akademik mahasiswa dapat dilihat dari nilai dari hasil anova atau $\mathrm{F} \alpha$ di dapat 323 tingkay Sig F=0,727>0,05 maka dapat di katakana H0 diterima yang artinya tidak ada pengaruh signifikan dampak media sosial instagram terhadap prestasi akademik mahasiswa.

3. Instagram bem fisip uniska dapat mempengaruhi terhadap tingkat kerajinan mahasiswa pada output test results menjelaskan nilai Box'M diperoleh 704 dengan nilai Sig $0,715>\alpha(0,05)$ maka $\mathrm{H} 0$ yang artinya tidak ada pengaruh signifikan dari instagram bem fisip uniska terhadap tingkat kerajinan mahasiswa.

\section{SARAN}

Berdasarkan hasil penelitian ini diketahui bahwa instagram sedikit banyaknya mempengaruhi sikap dan perilaku serta prestasi akademik mahasiswa Fisip Uniska :

1. Instagram bem fisip uniska yang di peruntukan untuk mahasiswa fisip uniska dari jurusan ilmu komunikasi dan administrasi publik seharusnya dimanfaatkan sebaik-baiknya karna di di sana lah mahasiswa dapat mengetahui kegiatan fakultas fisip yang akan dilaksanakan. 
2. Berbeda dengan instagram umum lainya instagram bem fisip uniska lebih terfokus dikegiatan-kegiatan kampus yang banyak sekali manfaatnya untuk lebih memajukan fakultas fisip.

3. Walaupun instagram bem fisip uniska tidak berpengaruh secara signifikan terhadap mahasiswa tapi tida salahnya jika mahasiswa lebih aktiv lagi untuk berorganisasi agar lebih mengerti tentang kagiatan-kegiatan diluar belajar yang ada sisi positifnya.

\section{REFERENSI}

Abdul Wahab Syahrani 2011, Pengaruh Komunikasi Organisasi Dan Kepemimpinan Terhadap Motivasi Kerja Pegawai Badan Kesatuan Bangsa Dan Politik Provinsi Kalimantan Selatan. Di Akses Pada Tanggal 20 Juni 2019

Ary Kristian Dewi 2017, Analisis Pengaruh Motivasi Dan Kepuasan Kerja Terhadap Kinerja Pegawai Pada Kantor Kesyahbandaran Dan Otoritas Pelabuhan (Kelav) Pulang Pisau. Di Akses Pada Tanggal 9 Juli 2019.

Drs.Jalaluddin Rakhmat,M.Sc 2004, Psikolog Komunikasi. Di Akses Pada Tanggal 19 Maret 2019

Dr. Ir Muhammad Yunus Jarmie, Ms. 2017 DasarDasar Statistik Komunikasi Terapan, Di Akses Pada Tanggal 15 April 2019.

Dr. Drs. H. Basuki MD, M.Si, Dr.Dra. Hj Rahmi Widyanti, M.Si 2017. Di Akses Pada Tanggal 16 April 2019.

Drs. Drs. H. Basuki MD, M.Si, Dr.Dra. Hj. Rahmi Widyanti, M.Si 2017, Statistika Terapan Dengan IBM SPSS Versi. 20. Di Akses Pada 20 Mei 2019.

Irwansyah Suwahyu 2015, Pengaruh Penggunaan Media Sosial Terhadap Akhlak Dan Prestasi Belajar Peserta Didik Di SMA UII YOGYAKARTA. Di Akses Pada Tanggal 9 Maret 2019.

I Gusti Ngurah Aditya Lesmana 2012, Analisis Pengaruh Media Sosial Twitter Terhadap Pembentukan Brand Attachment (Studi:Pt.X1 Axiata). Di Akses Pada Tanggal 9 Maret 2019.

John, Vivian 2008, Teori Komunikasi Massa. Di akses pada 15 Maret 2019.

Pedoman Penulisan Tesis Magister Uniska 2018.

Ngalim, Purwanto. Psikologi Pendidikan. Bandung : Remaja Karya. 1988. Akses pada 12 Maret 2018.

S. Notoatmodjo, Metodologi Pendidikan Dan Perilaku Kesehatan 2007. Di Akses Pada Tanggal 19 Maret 2019.

Website. http://uniska-bjm.ac.id/

Warner J. Severin- James W Tankard J 2009, Teori Komunikasi sejaeah, Metode dan Terapan di
Dalam Media Massa. Di Akses Pada Tanggal 19 Maret 2019. 